\title{
技術報告
}

\section{半導体用アルミナ基板におけるセラミックスーメタライズ 界面ガラス相の選択溶解/誘導結合プラズマ発光分析法}

\author{
竹内 由美 ${ }^{\circledR}$ ，若林 信一 ${ }^{*}$
}

(1990 年 2 月 21 日受理)

\begin{abstract}
タングステンメタライズーアルミナ界面のガラス相の選択分析法について検討した。試料のタングス テンメタライズをはく離し, ガラス相を露出させた後, $(1+5)$ 硫酸により $200^{\circ} \mathrm{C}, 1.5$ 時間の加圧酸 分解を行うことによりガラス相のみの選択溶解が可能であった。 そこで試料と同一濃度の硫酸及び標準 的な試料に含まれる $\mathrm{Al}, \mathrm{Si}, \mathrm{Mg}, \mathrm{Ca}$ を加えた標準液を用いて ICP-AES で分析を行った。その結果 溶出量としてサンプル当たり $\pm 0.1 \mathrm{mg}$, 組成比として $\mathrm{Al}_{2} \mathrm{O}_{3}, \mathrm{SiO}_{2}$ が士 $1 \mathrm{wt} \%, \mathrm{MgO}, \mathrm{CaO}$ が $\pm 0.5 \mathrm{wt} \%$ の精度でメタライズ中に浸透したガラス量及び組成の評価が可能となった。
\end{abstract}

\section{1 緒言}

半導体はプラスチックス, ガラス, セラミックスなど の材料により封止, 実装されているが, 機械的強度, 熱 的特性, 気密性, 耐薬品性なぞが重視される高信頼性基 板及びパッケージ材料としては, 多くはアルミナセラミ ックスが使用されている。この場合，アルミナには多層 積層技術により，数層にわたってタングステンによる導 体回路が形成されている.

従来，このようなメタライズ層はモリブデンーマンガ ンなざのペーストをセラミックス基板上に印刷し，焼成 する，後焼成法により作製されてきた。しかし，高密 度, 微細配線化が進行した現在では, ドクターブレード 成形したグリーンシートにタングステンペーストを印 刷, 積層して焼成する同時焼成法が広く採用されてい る.

メタライズ層のセラミックスへの接合機構1) は, Pincus $^{2}{ }^{2}$ によるアルミナと金属の化学結合説, Cole $^{3)}$ ら によるメタライズ層中へのガラスの浸透固着による物理 的結合説, があった。しかし, Nolte ら ${ }^{4) 5}$ はこれを修正 し，七ラミックス成分が共融混合物を生成し，金属表面 をぬらすと共に化学接合を行い, 金属粒子間へのガラス の浸透を促進することにより, 強固な接合を与えるとす る説, すなわち, 両説の複合機構が接合機構を支配する ことを指摘した。
その後, Chance $\mathrm{C}^{6)}$, 大塚ら”は同時焼成におけるタン グステンメタライズーセラミックスの接合機構について 検討し，基本的には後焼成の場合と同一の接合機構であ ることを示すと共に，メタライズ層とグリーンシートの 焼成収縮を精度よく一致させる必要があることを指摘し た.

この際，大塚ら》はタングステン層中へのガラス浸透 量を検討するに当たり，接合面の SEM 観察及び EPMA 分析を行い，接合強度を強くするうえで，セラ ミックスからタングステン層にわたって，フラックス成 分をできるだけ均一に分布させる必要があることを指摘 している．しかし，メタライズ層の接合に関与するガラ 又相について考えた場合, 従来, この問題に関して, 定 性・定量を目的とする，分析的な研究はほとんど発表さ れていないことが分かる. 従って, メタライズ層の接合 機構について, 上り詳細に検討しょうとする場合, 接合 面を直接観察すると共に, 接合に関与するガラス相の組 成及び生成量を正確に知る必要がある.

一般にセラミックス材料は試料の分解が難しく, 溶液 を試料之する機器分析では, 酸分解法又は融解法による 分解が行われている.このうち, テフロン密閉容器を使 用する加圧酸分解法 ${ }^{8)}$ は，七ラミックス上にガラス相が 存在する場合のように，表面組成の異なる面を持つ試料 については, 分解条件を検討することにより，一方を選 択的に溶解することが可能と考えられる. そこで, 電解 はく離法9)によりメタライズ層を除去し，ガラス相を露 出させた試料を作製して，接合に関与したガラス相のみ 
の選択溶解法について検討した. 次に，この溶液を試料 とし, ICP-AESにより定量した。 その結果アルミナー メタライズ界面に生成するガラス相の選択分析方法を確 立できたので報告する.

\section{2 実験}

\section{$2 \cdot 1$ 装}

ICP-AES 装置は日本ジャーレル・アッシュ製 ICAP-575 Mark II 型を使用したＩICP トーチは，同社 製高塩濃度用 (FT-2)，ネブライザーは同社製石英製ク ロスフロー型 (CRN-1), キャリヤーガスにはアルゴン を使用した。

\section{$2 \cdot 2$ 測定波長及び測定条件}

ICP による各元素の測定波長及び測定条件は，感度 が高く，しかも共存元素によるスペクトル妨害のないよ う考慮して，Table 2 のように選定した。

\section{$2 \cdot 3$ 試料及び試薬}

測定用試料は次のように作製した。 まず，セラミック ス組成を Table 1 のとおりとし，この組成の無機粉末 をアルミナボールと共にポットに入れ，メタノール，可 塑㓮，結合剤をそれぞれ 22.78，2.97，7.32 wt\% になる よう添加して，ボールミルにより十分混練し，無機粉末 $66.93 \mathrm{wt} \%$ のスリップを得た．次にこのスリップを使用 してドクターブレード法によりグリーンシートを成形

Table 1 Composition of alumina ceramics (wt \%)

\begin{tabular}{cccc}
\hline $\mathrm{Al}_{2} \mathrm{O}_{3}$ & $\mathrm{SiO}_{2}$ & $\mathrm{MgO}$ & $\mathrm{CaCO}_{3}$ \\
92.0 & 5.2 & 2.0 & 0.8 \\
\hline
\end{tabular}

Table 2 ICP-AES analytical conditions

\begin{tabular}{|c|c|c|c|}
\hline \multicolumn{4}{|c|}{ Operation conditions } \\
\hline & R. F Power & \multicolumn{2}{|c|}{$1.4 \mathrm{~kW}$} \\
\hline & Carrier gas & \multicolumn{2}{|c|}{$0.5 \mathrm{l} / \mathrm{min}$} \\
\hline & Plasma gas & \multicolumn{2}{|c|}{$0.9 \mathrm{l} / \mathrm{min}$} \\
\hline & Coolant gas & \multicolumn{2}{|c|}{$16 \mathrm{l} / \mathrm{min}$} \\
\hline & Observation height & \multicolumn{2}{|c|}{$15 \mathrm{~mm}$} \\
\hline & Slit & \multicolumn{2}{|c|}{10,10} \\
\hline & Signal measurement & \multicolumn{2}{|c|}{5 times } \\
\hline & Integration & \multicolumn{2}{|c|}{$5 \mathrm{~s}$} \\
\hline \multicolumn{4}{|c|}{ Analytical lines/nm } \\
\hline $\mathrm{Al}$ & 396.155 & $\mathrm{Mg}$ & 279.55 \\
\hline $\mathrm{Si}$ & 251.61 & $\mathrm{Ca}$ & 396.89 \\
\hline
\end{tabular}

し,これを，110 mm 角に型抜きした後，両面にタング ステンペースト（平均粒径 $1.3 \mu \mathrm{m}$ ) を印刷した。乾燥 後, $2.1 \mathrm{~cm} \times 3.0 \mathrm{~cm}$ に型抜きし, これを $1570^{\circ} \mathrm{C}$ の湿潤 雾囲気中で焼成し，メタライズ付きセラミックス試験片 とした．次にこの試料を $10 \% \mathrm{NaOH}$ 溶液中で陽極電 解)することにより，タングステンメタライズをはく離 し，タングステンメタライズ中に浸透したガラス相を露 出させ, 分析用試料とした.

測定元素 (4 元素, Table 2 参照) の標準溶液はすべ て和光純薬工業製原子吸光分析用金属標準夜 (いずれも $1 \mathrm{mg} / \mathrm{ml})$ から調整した.

メタライズ層中に浸透したガラス相の酸分解条件の検 討に用いた酸（塩酸, リン酸, 硫酸及びフッ化水素酸) は和光純薬工業製特級試薬である.

\section{$2 \cdot 4$ 選択溶解条件と溶液の調製}

$2 \cdot 3$ で作製した試料を半分に切断し，テフロン製加圧 分解容器 ${ }^{10)}$ (三愛科学製 $\mathrm{N}-25$ 型, 内容量 $25 \mathrm{ml}$, 耐熱 温度 $\left.250^{\circ} \mathrm{C}\right)$ に入れ, 各種酸の濃度を $(1+2)$, $(1+3),(1+4),(1+5)$, 分解時間を $0.5,1.0,1.5$, 2.0 時間, 分解温度を $180^{\circ} \mathrm{C}, 200^{\circ} \mathrm{C}, 230^{\circ} \mathrm{C}$ と変化さ せ, ガラス相の選択溶解条件について検討した。各条件 下で分解終了後, 加圧容器を室温程度まで急冷し, 試料 をよく洗净して取り出した後, この溶液を純水で 100 $\mathrm{ml}$ に調製して ICP 分析用試料溶液とした. 又溶解後の 試料表面はSEM 観察によりガラスの残存状態なざを観 察し，適正な選択溶解が行われたかだうかの目安とし た。 又, 比較として，メタライズ層を印刷しなかったセ ラミックス試料についても, 同様の操作により分析を行 った。

\section{3 結果及び考察}

\section{$3 \cdot 1$ 選択溶解条件}

まず，メタライズ層中に浸透したガラス相を選択溶解 するのに適当な酸について検討した．酸として，塩酸，

リン酸, フッ化水素酸, 硫酸を使用し, $200^{\circ} \mathrm{C}, 4$ 時間 の条件で分解したところ, 塩酸とリン酸ではガラス相が 溶解されず, 又フッ化水素酸ではセラミックスまで溶解 され, 不適当で, アルミナでの分解例 $\left.{ }^{11}\right)^{1}$ 報告されて いる硫酸が一番好ましいことが分かった. よって溶解酸 としては硫酸を用いることにした。

次に，比較としてのメタライズ層を持たないセラミッ クスと,メタライズ層をはく離したセラミックス試験片 について, 分解条件を変化させて分解時間とセラミック ス成分の単位面積当たりの溶出量の関係を求めた。 
まず，セラミックスそのものの分解に及ぼす分解条件 の影響について調べた結果を Fig. 1 に示す. Fig. 1 よ り, 分解温度が $230^{\circ} \mathrm{C}$ の場合, 硫酸濃度にかかわらず 分解時間が 1 時間以上では急速にセラミックスの分解 が進行することが分かる. 又, この際硫酸濃度 $(1+5)$ の場合, 1 時間の分解で $0.07 \mathrm{mg} / \mathrm{cm}^{2}$ の溶出が見ら れ, 組成は $38 \% \mathrm{Al}_{2} \mathrm{O}_{3}-40 \% \mathrm{SiO}_{2}-13 \% \mathrm{MgO}-9 \% \mathrm{CaO}$ であったが, 2.0 時間では $0.9 \mathrm{mg} / \mathrm{cm}^{2}$ が溶出し, 組成

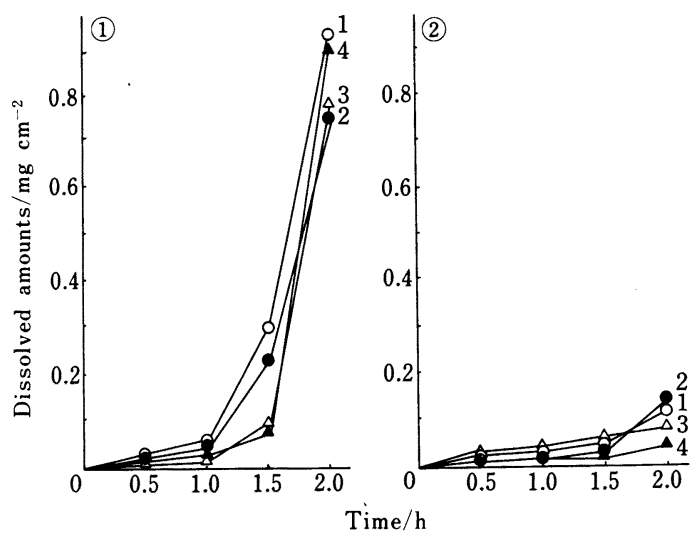

Fig. 1 Dissolved amounts of non-metallized alumina ceramics in sulfuric acid

Sulfuric acid concentration- $1: 1+2,2: 1+$ $3,3: 1+4,4: 1+5 ;$ Temperature : (1) $230^{\circ} \mathrm{C}$, (2) $200^{\circ} \mathrm{C}$
は $75 \% \mathrm{Al}_{2} \mathrm{O}_{3}-16 \% \mathrm{SiO}_{2}-4 \% \mathrm{MgO}-4 \% \mathrm{CaO}$ であった ことから, はじめは表面のガラス相の溶解が起こり, 続 いてセラミックスの溶解が起こったものと考えられる.

一方, $200^{\circ} \mathrm{C}$ の場合, いずれの条件でも 1.5 時間まで の溶出量は少なく, 2.0 時間でもわずかに増加が見られ る程度であった．硫酸濃度 $(1+5)$ の条件では 2.0 時間 の分解で $0.05 \mathrm{mg} / \mathrm{cm}^{2}$ の溶出しか起こらず, その組成

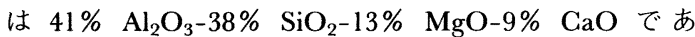
り，七ラミックス表層の粒界にあるガラス相のみが溶出 し，下層のセラミックスの溶出はほとんど起こらなかっ た。

次に,メタライズ層をはく離したセラミックス試験片 を使用して，同様の実験を行った結果をFig. 2 に示 す. まず分解温度が $230^{\circ} \mathrm{C}$ の場合, 硫酸濃度 $(1+2)$, $(1+3),(1+4)$, では, 時間と共に溶出量が増加してお り，その組成も 1 時間までは $45 \% \quad \mathrm{Al}_{2} \mathrm{O}_{3}-29 \%$ $\mathrm{SiO}_{2}-16 \% \mathrm{MgO}-10 \% \mathrm{CaO}$ とほぼ一定であったが, 1.5 時間では $\mathrm{Al}_{2} \mathrm{O}_{3} 60 \%$ と $\mathrm{Al}_{2} \mathrm{O}_{3}$ の比率が高くなることが 分かった。硫酸濃度 $(1+5)$ の場合は, 0.5 時間〜 1.5 時間の間で溶出量が $0.4 \mathrm{mg} / \mathrm{cm}^{2}$ と一定になる傾向が見 られたが，1.5 時間後から溶出量が増加した。溶出した 成分の組成は 1.5 時間までは $40 \% \quad \mathrm{Al}_{2} \mathrm{O}_{3}-30 \%$ $\mathrm{SiO}_{2}-15 \% \mathrm{MgO}-10 \% \mathrm{CaO}$ でほぼ一定であったが, 1.5 時間以降の $\mathrm{Al}_{2} \mathrm{O}_{3}$ の比率が高くなったことから，メ夕 ライズ層中に浸透したガラス相が溶解した後, セラミッ クスそのものの溶出が進行したものと考えられる. 従っ
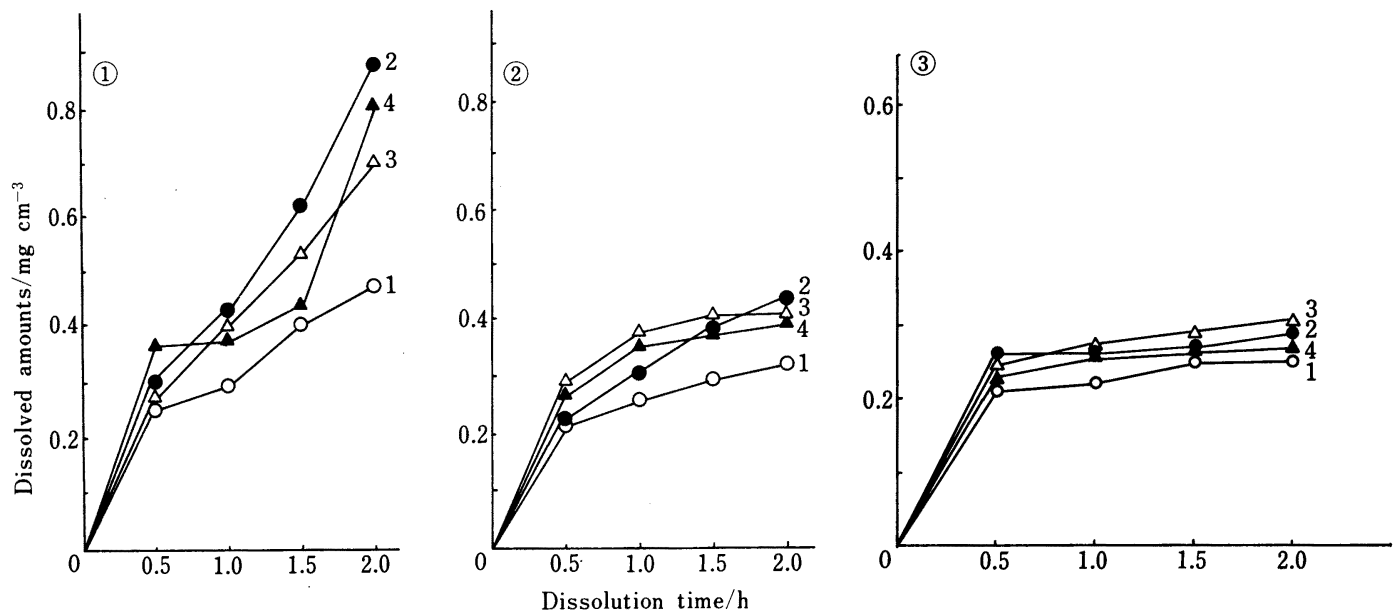

Fig. 2 Dissolved amounts of alumina ceramics with glassy phase formed by W metallization

Sulfuric acid concentration $-1: 1+2, \quad 2: 1+3 \quad 3: 1+4, \quad 4: 1+5$; Temperature : (1) $230^{\circ} \mathrm{C}$, (2) $200^{\circ} \mathrm{C}$, (3) $180^{\circ} \mathrm{C}$ 

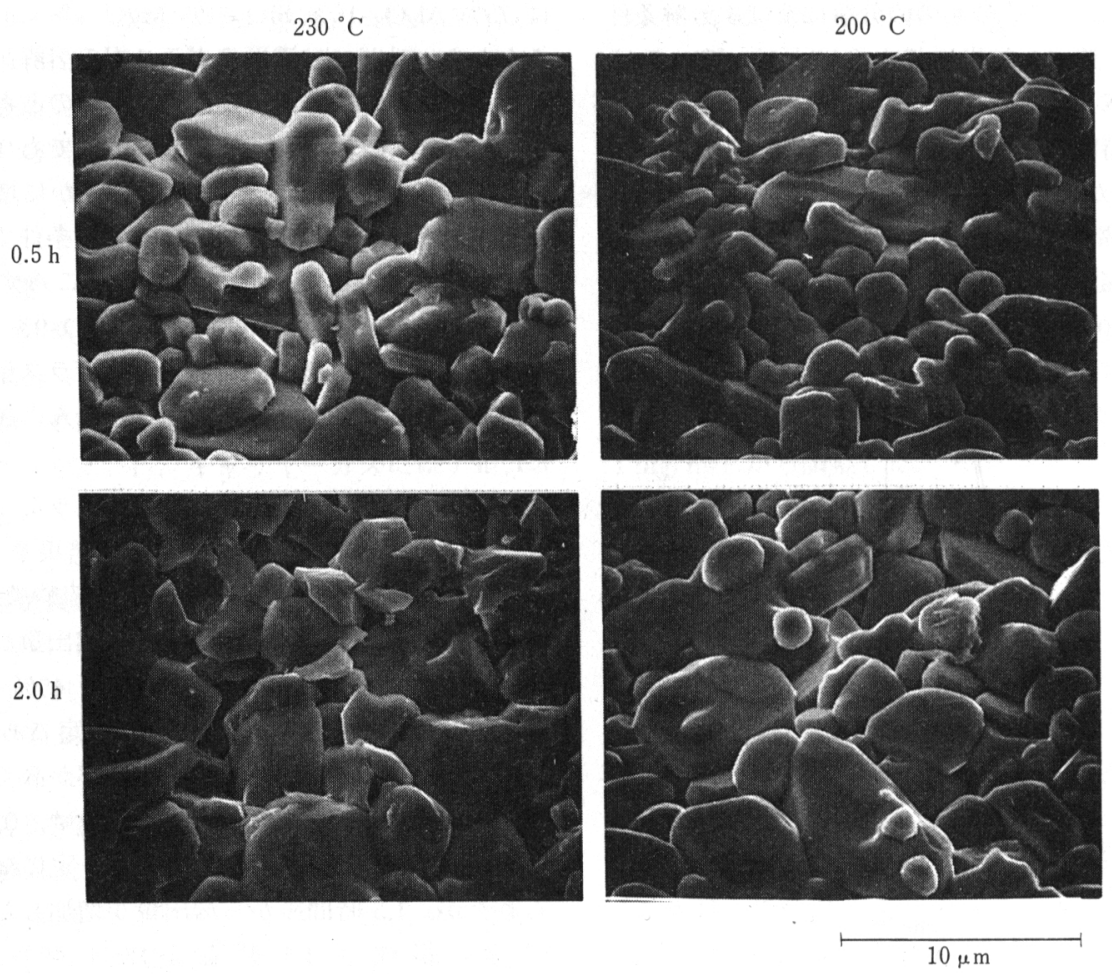

Fig. 3 Surfaces of non-metallized alumina ceramics after treatment with sulfuric acid

て選択性は低いものの, 他に比べ硫酸濃度が低いことか ら多少の選択性が働いたものと考えられる。

一方, $200^{\circ} \mathrm{C}$ の場合, 硫酸濃度 $(1+3),(1+4)$, $(1+5)$ では, 分解時間 1.0 時間で溶出量が約 0.4 $\mathrm{mg} / \mathrm{cm}^{2}$ と一定值に達し, 組成比も $40 \% \quad \mathrm{Al}_{2} \mathrm{O}_{3}-30 \%$ $\mathrm{SiO}_{2}-15 \% \mathrm{MgO}-10 \% \mathrm{CaO}$ と一定となった.これは森 川ら ${ }^{11)}$ の報告にもあるように，アルミナの分解は $200^{\circ} \mathrm{C}$ では不十分のため, メタライズ層中に浸透したガラス相 がすべて溶解し，七ラミックス面に到達したところで溶 解反応が停止したため, すなわちガラス相のみの選択溶 解が行われたものと考えられる. 又硫酸濃度 $(1+3)$ で はアルミナが溶解しやすかったが，これは森川ら ${ }^{11)}$ Gitzen $^{12)}$ の結果と一致しており彼らによると熱水が高 温, 加圧下でアルミナ焼結体と反応を示すためと報告さ れている.

更に, 分解温度を $180^{\circ} \mathrm{C}$ とした場合, いずれの硫酸 濃度でも溶出量は 0.5 時間で約 $0.25 \mathrm{mg} / \mathrm{cm}^{2}$ に到達 し,それ以降ほぼ一定值を示すことから，180C では十 分ガラス相の分解が進まないことが分かる.
そこで, 上記の分解処理を行った場合の試料表面変化 を観察した。メタライズ層を持たないセラミックスを， 硫酸濃度 $(1+5)$ とし, $230^{\circ} \mathrm{C}$ 及び $200^{\circ} \mathrm{C}$ で処理した 場合のセラミックス表面を Fig. 3 に示す.これより分 解温度が $230^{\circ} \mathrm{C}$ の場合, 分解時間が 2.0 時間を超える と, アルミナ粒の形がシャープになり, アルミナの溶解 が進んでいることが分かる. 一方, 分解温度が $200^{\circ} \mathrm{C}$ の場合は 2.0 時間でも, アルミナ粒界が明確になるのみ でアルミナ粒そのものは変化なく, アルミナの溶解は進 まないことが分かる. 同様に, メタライズ層をはく離し たセラミックス表面の変化を観察した結果を Fig. 4 に 示す.白く見える部分がメタライズ層中に浸透したガラ ス相であり, 分解温度が $230^{\circ} \mathrm{C}$ の場合, 1.5 時間でガラ ス相は完全に溶解し, メタライズ層はく離時の残留物と アルミナ粒が観察される. 又, 2.0 時間では更に溶解が 進みセラミックスが溶解し始めていることが分かる。一 方, 分解温度が $200^{\circ} \mathrm{C}$ の場合, 分解時間 1.0 時間で約 $80 \%, 1.5$ 時間で完全にガラス相が溶解している. しか も, セラミックスの溶解は観察されず, ガラス相が選択 

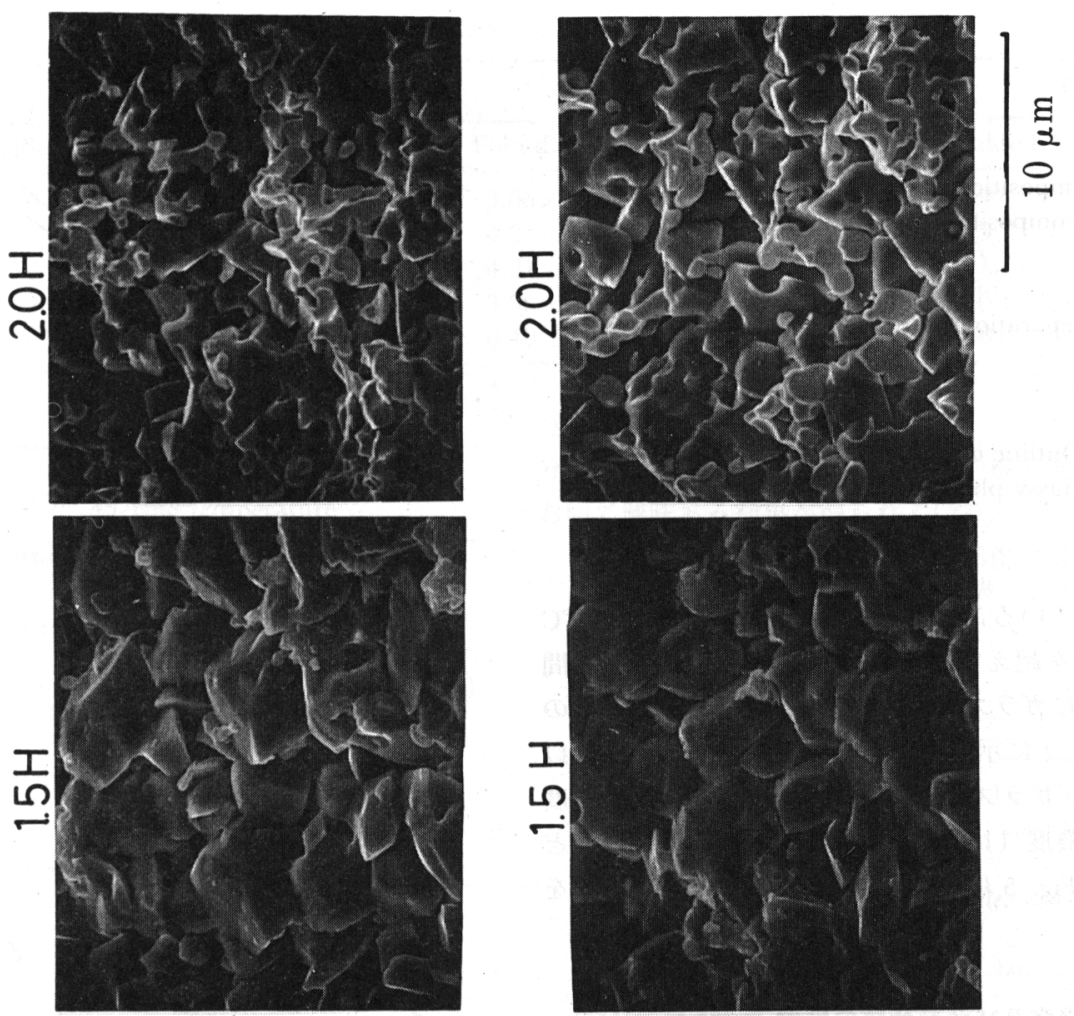

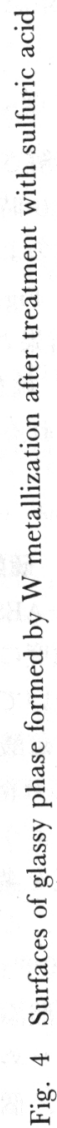

N
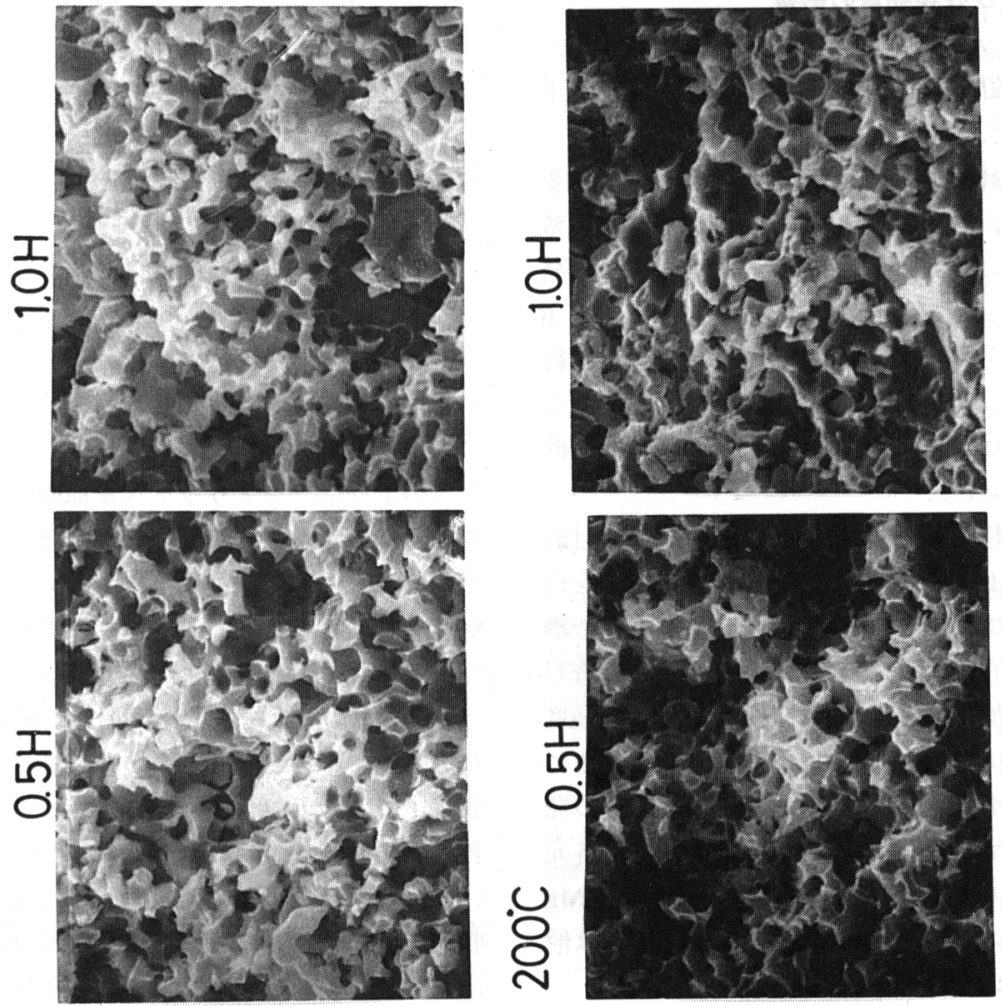


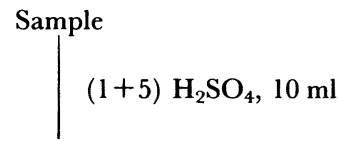

Decomposition (in a Teflon pressurized decomposition vessel) : $200^{\circ} \mathrm{C}, 1.5 \mathrm{H}$<smiles>C=C</smiles>

Preparation of the volume, $100 \mathrm{ml}$

to ICP

Fig. 5 Outline of decomposition procedure for glassy phase with $\mathrm{H}_{2} \mathrm{SO}_{4}$

的に溶解されていることが分かる. 又分解温度が $180^{\circ} \mathrm{C}$ では 2.0 時間を超えてもその表面は Fig. 4 の 0.5 時間 の表面のようにガラス相は溶解されなかった。これらの 結果はFig. 1, 2 に示した溶出結果と一致している. 以 上の結果からガラス相の選択溶解条件は, 分解温度 $200^{\circ} \mathrm{C}$, 硫酸濃度 $(1+5)$, 分解時間 1.5 時間が最適と 考えられる. Fig. 5 にこの分解操作のフローチャートを 示す.

\section{$3 \cdot 2$ 硫酸蓝度及び共存物質の影望}

ICP-AES による $\mathrm{Al}, \mathrm{Si}, \mathrm{Mg}, \mathrm{Ca}$ の分析において, 発光強度に及ぼす硫酸の影響とそれらの元素間の相互干 渉について検討した。

ます硫酸添加の影響について, 各測定元素の濃度を変 化させた溶液及び，これに（1+5）の硫酸が $10 \mathrm{vol} \%$ になるように添加した溶液を作製し，各分析波長での発 光強度を調査した. $\mathrm{Al}$ の場合の発光強度変化を Fig. 6 に示す.これより, 硫酸添加により $\mathrm{Al}$ の発光強度は約 $10 \%$ 低下した. 又, $\mathrm{Si}, \mathrm{Mg}, \mathrm{Ca}$ も同様であった。こ れは硫酸添加により溶液の粘度が上昇し, 吸引効率が低 下したためと考えられる.

次に，個々の元素による相互の干渉を調査する目的 で, Al $10 \mathrm{ppm}$, Si $10 \mathrm{ppm}, \mathrm{Mg} 3 \mathrm{ppm}$, Ca $3 \mathrm{ppm}$ を含 む溶液を調製し，これにそれぞれ 1〜20 ppm の間で濃 度を変化させて添加した場合の発光強度の変化を調査し た. Fig. 7 に Si 添加量による $\mathrm{Al}, \mathrm{Mg}, \mathrm{Ca}$ の発光強度 の変化を示す. その結果 $\mathrm{Si}$ を $10 \mathrm{ppm}$ 添加することに より $\mathrm{Al}$ は約 $10 \%$ 発光強度が増加し, $\mathrm{Mg}$ と $\mathrm{Ca}$ の発 光強度は逆に約 $10 \%$ 低下することが分かった．又各元 素の溶液に $\mathrm{Al}$ を $10 \mathrm{ppm}$ 添加した場合には $\mathrm{Si}$ と $\mathrm{Mg}$ の発光強度が約 $5 \%$ 低下した. しかし $\mathrm{Mg}$ と $\mathrm{Ca}$ は他 元素の発光強度に影響を与えなかった。

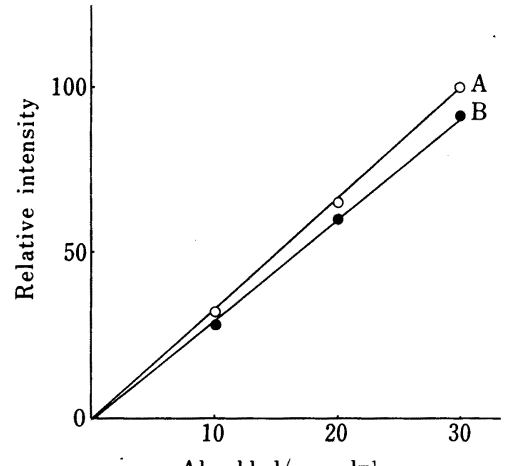

Al added $/ \mu \mathrm{g} \mathrm{ml}^{-1}$

Fig. 6 Matrix effect by sulfuric acid on A calibration curve

Matrix A : none added B : $1.7 \% \mathrm{H}_{2} \mathrm{SO}_{4}$

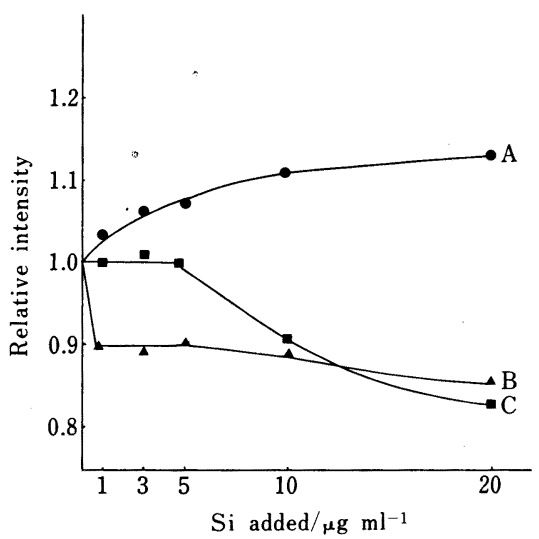

Fig. 7 Effect. of $\mathrm{Si}$ concentrations on $\mathrm{Al}, \mathrm{Mg}, \mathrm{Ca}$ emission intensities

A : Al $10 \mu \mathrm{g} \mathrm{ml}^{-1} ; \mathrm{B}: \mathrm{Mg} 10 \mu \mathrm{g} \mathrm{ml}^{-1} ; \mathrm{C}: \mathrm{Ca} 10$ $\mu \mathrm{g} \mathrm{ml}^{-1}$

このように，マトリックスを構成する共存物質によ て各元素の測定波長領域における発光強度が影響を受 た.そこであらかじめ $\mathrm{Al} 500 \mu \mathrm{g} / \mathrm{ml}, \quad$ Si $500 \mu \mathrm{g} / \mathrm{ml}$ $\mathrm{Mg} 50 \mu \mathrm{g} / \mathrm{ml}, \mathrm{Ca} 50 \mu \mathrm{g} / \mathrm{ml}$ に調製した水溶液から， $2,3 \mathrm{ml}$ を採取し， $50 \mathrm{ml}$ のメスフラスコに移し，ここ $(1+5)$ の硫酸 $10 \mathrm{vol} \%$ を添加し，純水で標線に調製 た溶液を標準液とした。この標準液を用いて検量線を 成し, 各元素の混合比率を変化させた混合試料溶液中 各元素濃度を分析した。この結果を Table 3 に示す いずれの系についても添加量に対し $\pm 0.2 \mathrm{ppm}$ 程度内 収まる分析值が得られた．従って実試料を分析する際 はマトリックスを補正した標準液を用いて分析するこ 
Table 3 Analytical results for synthetic solutions $(\mu \mathrm{g} / \mathrm{ml})$

\begin{tabular}{|c|c|c|c|c|c|c|c|c|}
\hline \multirow{2}{*}{ No. } & \multicolumn{2}{|c|}{ Al } & \multicolumn{2}{|c|}{$\mathrm{Si}$} & \multicolumn{2}{|c|}{$\mathrm{Mg}$} & \multicolumn{2}{|c|}{$\mathrm{Ca}$} \\
\hline & Added & Found & Added & Found & Added & Found & Added & Found \\
\hline 1 & 30 & 29.55 & 3 & 3.06 & 3 & 3.03 & 9 & 8.98 \\
\hline 2 & 9 & 8.80 & 4 & 4.24 & 1 & 1.00 & 5 & 4.97 \\
\hline 3 & 4 & 3.92 & 4 & 4.21 & 2 & 2.03 & 1 & 1.00 \\
\hline 4 & 12 & 11.76 & 3 & 3.06 & 6 & 6.15 & 0.7 & 0.72 \\
\hline 5 & 20 & 19.36 & 0.5 & 0.40 & 1.3 & 1.36 & 8 & 8.14 \\
\hline
\end{tabular}

Table 4. Analytical results for glassy phase formed at different sintering temperature

\begin{tabular}{lcc}
\hline \multirow{2}{*}{ Constituent } & \multicolumn{1}{c}{ Sintering temperature } \\
& $157 \overbrace{}^{\circ} \mathrm{G}$ & $1550^{\circ} \mathrm{C}$ \\
\hline & Dissolution amount $(\mathrm{mg} /$ sample $)(n=5)$ \\
$\mathrm{Al}_{2} \mathrm{O}_{3}$ & $1.31 \pm 0.09$ & $1.06 \pm 0.1$ \\
$\mathrm{SiO}_{2}$ & $0.93 \pm 0.02$ & $0.76 \pm 0.05$ \\
$\mathrm{MgO}$ & $0.44 \pm 0.02$ & $0.35 \pm 0.05$ \\
$\mathrm{CaO}$ & $0.29 \pm 0.01$ & $0.24 \pm 0.02$ \\
Total & $2.96 \pm 0.1$ & $2.49 \pm 0.1$ \\
\hline
\end{tabular}

とした.

次に $92 \% \mathrm{Al}_{2} \mathrm{O}_{3}-5.2 \% \mathrm{SiO}_{2}-2.0 \% \mathrm{MgO}-0.8 \% \mathrm{CaO}$ のアルミナセラミックスを, Fig. 5 に示した操作に基づ いて溶解し，マトリックスを補正した標準液を用いてそ の組成を分析したところ, 各成分とも調製時の組成に対 し $\pm 0.1 \sim 0.5 \%$ の分析值が得られた.

\section{$3 \cdot 3$ 実試料の分析}

$2 \cdot 3$ の条件で作製したメタライズ層付きシートを 5 個 ずつ $1550^{\circ} \mathrm{C}$ 及び $1570^{\circ} \mathrm{C}$ で焼成した後, Fig. 5 に示し た操作により，メタライズ層中に浸透したガラス相を定 量分析した. その結果を Table 4 に示す. メタライズ 層中に浸透するガラス量は焼成温度が高くなるにつれ増 加する傾向があると言われているが，この結果もそれを 裏付けており, 焼成温度が $20^{\circ} \mathrm{C}$ の差であっても, ガラ ス浸透量の違いを分析評価することが可能である. 又そ の繰り返し精度も, 溶出量として 1 サンプル当た り $0.1 \mathrm{mg}$, 組成比として $\mathrm{Al}_{2} \mathrm{O}_{3}, \mathrm{SiO}_{2}$ が土1 wt \%, $\mathrm{MgO}, \mathrm{CaO}$ が $0.5 \mathrm{wt} \%$ と高く, メタライズ層中に浸透 したガラス量及び組成の評価として十分であると考え る.

現在, 上記の方法を用いて, 種々の組成のアルミナセ ラミックスにおけるメタライズ層中に浸透したガラスの
分析を行っており，メタライズ層の接着強度との関係に おいて興味ある結果が得られている.

$\left(\begin{array}{l}1988 \text { 年 } 10 \text { 月, 第 } 18 \text { 回中部化学関係学協会連 } \\ \text { 合秋季大会において一部発表 }\end{array}\right)$

\section{文献}

1) 上山 守: エレクトロニクセラミックス, 11 月号, p. 27 (1988).

2) A. G. Pincus: Ceram. Age, 63, 16 (1954).

$3)$ S. S. Cole, F. J. Hynes: Am. Cera. Soc. Bull., 37 ( 3 ), 135 (1958).

4) H. J. Notle, R. F. Spurk : Television Eng., 1 (11), 14 (1950).

5) S. S. Cole, G. Sommer:J. Am. Ceram. Soc., 44 ( 6 ), 265 (1961).

6) D. A. Chance: Metallurgical Trans., 1, 685 (1970).

7) K. Otsuka, T. Vsami, M. Sekihata: Am. Ceram. Soc. Bull., 60, 540 (1981).

8）内田哲男: ぶんせき, 1986, 9.

9）松村源太郎訳：“金属エッチング技術”, 第 2 版, (1982)，（アグネ技術センター)； \{G. Petzow： “Metallo Graphisches Ätzen”, (1976), (Gebrüder, Borntraeger, Berlin, Stuttgart)\}.

10) 内田哲男: ぶんせき, 1986, 71.

11）森川 久, 飯田康夫, 石塚紀夫, 横田文夫 : 分析化 学, 35, 636 (1986).

12) W. H. Gitzen : "Alumina as a Ceramic Material", p. 103 (1970), (The American Ceramic Society, Inc., Ohio).

$$
\text { 幽 }
$$

Analysis of glassy phase formed at interface of metallized alumina for semiconductor substrate by ICP-AES after selective dissolution. Yumi TAKEUCHI and Shinichi Wakabayashi (SHINKO Electric Industries Co., Ltd., 711, Kurita, Nagano-shi, Nagano 380)

Elemental analysis of a glassy phase at metallized alumina interface by ICP-AES following selective dissolution was studied. A test sample was prepared by printing tungsten paste on a green sheet $\left(92 \% \mathrm{Al}_{2} \mathrm{O}_{3}-5.2 \%\right.$ $\left.\mathrm{SiO}_{2}-2 \% \mathrm{MgO}-0.8 \% \quad \mathrm{CaCO}_{3}\right)$ and by sintering at $1570^{\circ} \mathrm{C}$. The glassy phase formed was exposed by removing the metal layer by anodic stripping in $10 \%$ 
$\mathrm{NaOH}$ solution. Selective decomposition conditions for the glassy phase with sulfuric acid were studied using a Teflon pressurized decomposition vessel. The optimum decomposition was achieved at $200^{\circ} \mathrm{C}$ for $1.5 \mathrm{~h}$ with $(1+$ 5) sulfuric acid. In the ICP-AES determination, sulfuric acid reduced the emission intensities of $\mathrm{Al}, \mathrm{Si}, \mathrm{Mg}, \mathrm{Ca}$ by approximately $10 \%$. In order to compensate for the matrix effect, the use of a standard solution containing the same concentration of sulfuric acid as that in sample solution, $10 \mu \mathrm{g} / \mathrm{ml}$ of $\mathrm{Al}$ and $\mathrm{Si}$, and $3 \mu \mathrm{g} / \mathrm{ml}$ of $\mathrm{Mg}$ and $\mathrm{Ca}$ was required. Variation of the total dissolved amount per sample was within $0.1 \mathrm{mg}(n=5)$ and those of the chemical composition were $\pm 1 \%$ for $\mathrm{Al}_{2} \mathrm{O}_{3}$ and $\mathrm{SiO}_{2}, \pm 0.5 \%$ for $\mathrm{MgO}$ and $\mathrm{CaO}$ by the proposed method.

(Received Feburary 21, 1990)

\section{Keyword phrases}

selective analysis of glassy phase; alumina-tungsten metallization; ICP-AES; acid pressurized decomposition vessel. 